\title{
Effect of Chemical Fertilizer, Organic Manure and Bio-Fertilizer on Growth and Yield of Summer Cowpea (Vigna unguiculata L. Walp)
}

\author{
Dhwani Bartwal and R. A. Patel ${ }^{*}$ \\ Department of Agronomy, B. A. college of Agriculture, Anand Agricultural University, \\ Anand, Gujarat, India \\ *Corresponding author
}

\section{A B S T R A C T}

\section{Keywords \\ Cowpea, Castor cake, FYM, \\ Vermicompost, \\ Rhizobium, PSB \\ Article Info \\ Accepted: \\ 07 October 2020 \\ Available Online: \\ 10 November 2020}

A field experiment was conducted during summer season of the year 2018 on loamy sand soil at College Agronomy Farm, B. A. College of Agriculture, Anand Agricultural University, Anand to evaluate the effect of chemical fertilizer, organic manure (Castor cake, Vermicompost and FYM) and bio-fertilizers (Rhizobium and PSB) on growth and yield of summer cowpea (Vigna unguiculata L. Walp).Significantly higher growth attributes (plant height $(\mathrm{cm})$ and higher number of branchesplant ${ }^{-1}$ )was recorded under application of recommended dose of chemical fertilizer 20-40-00 NPK kg ha- and remained at par with application of $4 \mathrm{t} \mathrm{FYM} \mathrm{along} \mathrm{with} 5 \mathrm{ml} \mathrm{PSB} \mathrm{kg}^{-1}$ seed. Application of recommended dose of chemical fertilizer 20-40-00 NPK kg ha ${ }^{-1}$ recorded significantly higher yield attributes (numbers of pod plant ${ }^{-1}$ and numbers of seeds pod ${ }^{-1}$ ) and seed and stover yield $\left(\mathrm{kg} \mathrm{ha}^{-1}\right)$ over rest of the treatments. However, it was at par with application of

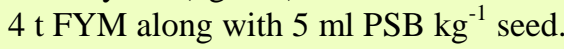

\section{Introduction}

Pulses are the second most important group of crop after cereals. To heighten the public awareness of nutritional benefits of pulses as a part of sustainable food security and nutrition, year 2016 was declared as "International Year of Pulses" by the United Nation. Pulses accounts for around $20 \%$ of the area under food grains and contribute around 7 to $10 \%$ of total food grain production in the country (Mohanty and Satyasi, 2015). In India pulses are grown in an area of 25.21 million ha with total production of 19.78 million tons with productivity of $763 \mathrm{~kg} / \mathrm{ha}$. While in Gujarat, it is grown over an area of 6.54 million ha with an annual production of 5.99 lakh tons with average productivity of $916 \mathrm{~kg} / \mathrm{ha}$ in the year 2014-15 (Anonymous, 2016). About a dozens of pulse crops viz., chickpea, pigeon pea, mung bean, urdbean, lentil, field pea, lathyrus, cowpea, common bean, mothbean horse gram and rice bean are generally cultivated under varied agro-ecological conditions. Among them, cowpea (Vigna unguiculata L. Walp) has its origin from India and Ethiopia and is widely grown all over the world. Cowpea serves as a dual purpose food at both green shell and dry stage. In the 
current context with the advancement in the knowledge, technology and concern about the ecosystem, more emphasis is being given to the alternative sources of nutrients than fertilizers alone for maintaining the sustainability of environment. In view of this liquid biofertilizers and various organics supplements are also being focused along with chemical fertilizers.

\section{Materials and Methods}

A field experiment was conducted at College Agronomy Farm, B.A College of Agriculture, Anand Agricultural University, Anand (Gujarat)during summer season of the year 2018. The soil of experimental site was loamy sand in texture, having low in organic carbon and available nitrogen (124.85 kg ha-1), medium in available $\mathrm{P}_{2} \mathrm{O}_{5}\left(29.23 \mathrm{~kg} \mathrm{ha}^{-1}\right)$ and high in available $\mathrm{K}_{2} \mathrm{O}\left(286.76 \mathrm{~kg} \mathrm{ha}^{-1}\right)$. Cowpea variety Gujarat cowpea 4 (GC 4) was used as a test crop in the study. The experiment was arranged in randomized block design with four replications, consisting of twelve treatments $\mathrm{T}_{1}$ : No fertilizer (control), $\mathrm{T}_{2}$ : RDF 20-40-00 kg ha-1 (NPK), $\mathrm{T}_{3}$ : Castor cake@0.5 tha ${ }^{-1}, \mathrm{~T}_{4}$ : Vermicompost @ $1 \mathrm{tha}$ ${ }^{1}, \mathrm{~T}_{5}$ : FYM @ $4 \mathrm{t} \mathrm{ha}^{-1}, \mathrm{~T}_{6}$ : Castor cake @ $0.5 \mathrm{t}$ $\mathrm{ha}^{-1}+\mathrm{PSB} @ 5 \mathrm{~mL} \mathrm{~kg}{ }^{-1}$ seed, $\mathrm{T}_{7}$ : Vermicompost@1 $\mathrm{tha}^{-1}+$ PSB @ $5 \mathrm{~mL} \mathrm{~kg}^{-1}$ seed, T8: FYM @ $4 \mathrm{t} \mathrm{ha}^{-1}+\mathrm{PSB} @ 5 \mathrm{~mL} \mathrm{~kg}^{-1}$ seed, T9: Rhizobium @ $5 \mathrm{~mL} \mathrm{~kg}^{-1}$ seed + PSB @ $5 \mathrm{~mL} \mathrm{~kg}^{-1}$ seed, $\mathrm{T}_{10}$ : Castor cake @ $0.25 \mathrm{t}$ ha $^{-1}+$ Rhizobium @ $5 \mathrm{~mL} \mathrm{~kg}^{-1}$ seed + PSB @ $5 \mathrm{~mL} \mathrm{~kg}^{-1}$ seed, $\mathrm{T}_{11}$ : Vermicompost@0.5 t $\mathrm{ha}^{-1}+$ Rhizobium @ $5 \mathrm{~mL} \mathrm{~kg}^{-1}$ seed + PSB @ $5 \mathrm{~mL} \mathrm{~kg}{ }^{-1}$ seed and $\mathrm{T}_{12}$ : FYM @2 $\mathrm{t} \mathrm{ha}^{-1}+$ Rhizobium @ $5 \mathrm{~mL} \mathrm{~kg}^{-1}$ seed + PSB @ $5 \mathrm{~mL}$ $\mathrm{kg}^{-1}$ seed, each plot being $3.60 \mathrm{~m} \times 5.00 \mathrm{~m}$. Chemical fertilizer were applied through urea and DAP as per treatment. Organic manure comprising of castor cake and FYM were applied well in advance for proper decomposition whereas, vermicompost was applied on the day of sowing. The seeds were inoculated with respective strains of Rhizobium and PSB according to the treatment. Crop was harvested in second week of May. The data recorded during the course of investigation were subjected to statistical analysis as per method of analysis of variance (Panse and Sukhatme, 1978). Cowpea was sown on $21^{\text {st }}$ February with seed rate of $25 \mathrm{~kg}$ $\mathrm{ha}^{-1}$.

\section{Results and Discussion}

\section{Effect on growth attributes}

Data presented in Table 1 indicated that different treatments had a significant influence on growth attributes of cowpea such as plant height, number of branches plant ${ }^{-1}$ and number of root nodules plant $^{-1}$. Application of RDF 20-40-00 kg NPK ha ${ }^{1}\left(\mathrm{~T}_{2}\right)$ recorded significantly higher plant height $(43.83 \mathrm{~cm})$ and higher number of branches per plant (6.10)being at par with treatment FYM $4 \mathrm{t} \mathrm{ha}^{-1}$ + PSB $5 \mathrm{~mL} \mathrm{~kg}^{-1}$ seed, which might be due to the availability of nutrients from chemical fertilizer and favorable condition created in uptake of plant nutrients by the crop. Initial boost of nitrogen must have benefited the crop as nitrogen is also known to contribute for cell elongation. As nitrogenous fertilizer might have helped and the enhanced the development of strong cell walls and therefore stiffer branches which might resulted into profuse branches of cowpea. Application of phosphorus which must have helped in better proliferation of roots and increased nodulation resulted in to increased phosphorus availability, which must have encouraged the formation of new cells, promoted plant vigor and hastened leaf development, which helped in harvesting more solar energy and better utilization of nitrogen which resulted in to higher growth. Phosphorus is also known to encourage cell division and hence contributed to taller plants. 
Table.1 Effect of chemical fertilizer, organic manure and bio-fertilizers on growth and yield attributes and yield of cowpea

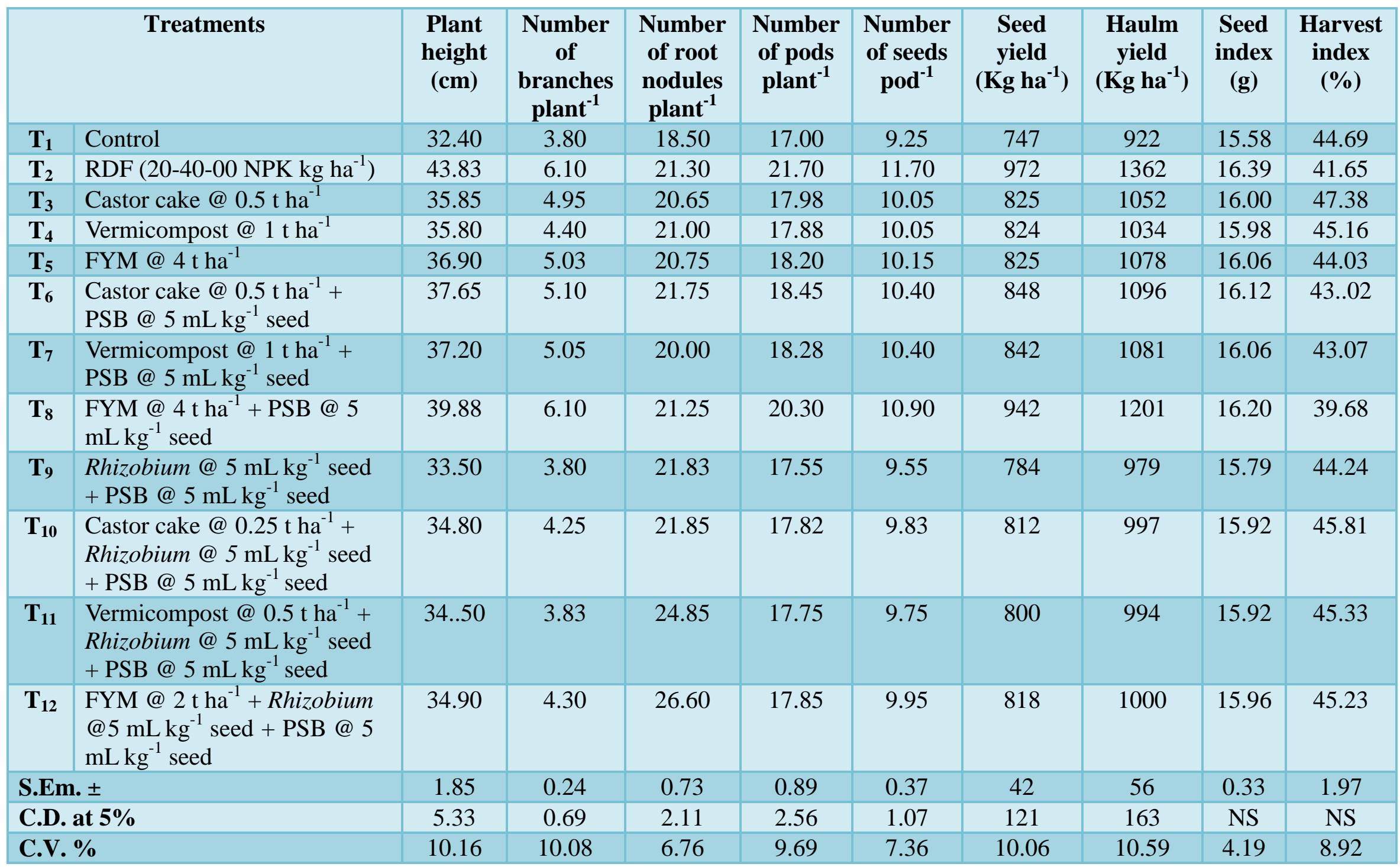


The results obtained in present investigation are in conformity with those of Gupta (2014), Meena et al., (2015) and Pargi et al., (2018). Further data revealed that the differences in number of root nodules plant ${ }^{-1}$ due to different treatments were found significant. Among different treatments, significantly higher number of root nodule plant $^{-1}$ (26.60) was recorded under treatment FYM @ $2 \mathrm{t} \mathrm{ha}^{-1}+$ Rhizobium@5 mL kg ${ }^{-1}$ seed + PSB @ $5 \mathrm{~mL}$ $\mathrm{kg}^{-1}$ seed and remained at par with treatment Vermicompost@0.5 tha ${ }^{-1}+$ Rhizobium @5 mL kg-1 seed + PSB @ $5 \mathrm{~mL} \mathrm{~kg}^{-1}$ seed with 24.85 root nodules plant ${ }^{-1}$. Increase in root nodules might be ascribed to better availability of nutrients through FYM at critical growth stages which facilitated improved nodulation along with inoculation of seeds with symbiotic nitrogen fixers which might have increased the concentration of an efficient and healthy strain of Rhizobium in rhizosphere, which in turn ascribed to stimulatory effect of bacteriods on root curling, bulging infection thread and ultimately the production of more infectious sites or nodules. The PSB liquid biofertilizer might also have enhanced the availability of phosphorus to plants which must have utilized in greater root development and nodulation. The results are in close agreement with the findings reported by Yadav and Malik (2005), Khandelwal (2007), Meena et al., (2015) and Pargi et al., (2018).

\section{Effect on yield attributes and yield}

Yield and yield attributes of cowpea were also influenced significantly due to various treatments. (Table 1). Application of RDF (20-40-00 NPK kg ha ${ }^{-1}$ ) recorded significantly higher number of pods plant ${ }^{-1}$ (21.70), number of seeds pod $^{-1}$, higher seed and haulm yield. Which was remained at par with treatment FYM@ $4 \mathrm{t} \mathrm{ha}^{-1}+$ PSB @ $5 \mathrm{~mL} \mathrm{~kg}^{-1}$ seed. A close observation on the seed index and harvest index shows that the treatment effect was incapable to exercise a significant result on the seed and harvest index of cowpea. More number of pods plant ${ }^{-1}$ might be due to more survival of flowers with high supply of photosynthates under treatment RDF as compared to other treatments. Phosphorus application played its primary role in photosynthesis by way of rapid energy transfer and there by increased photosynthetic efficiency and thus, increased total biomass production and translocation in plant parts. These altogether resulted into overall increase in number of pods. The higher number of seeds pod $^{-1}$ was obtained probably due to suppling of ample amount of nutrients in form of chemical fertilizer must have increased carbohydrate accumulation and their remobilization to reproductive parts of the plant, being closest sink and hence, resulted into increased flowering, fruiting and seed formation and thus more number of seeds $\operatorname{pod}^{-1}$. The probable reason for the higher yield may be due to combined application of nitrogen and phosphorus must have produced excess of assimilates which are first stored in leaves and later translocated into seeds at the time of senescence, which might have ultimately led to higher seed yield. Application of RDF in form of chemical fertilizer gave the highest haulm yield probably because of the fact that under this treatment the synthesis of photosynthetic is more owing to adequate supply of nitrogen and phosphorus which increased the photosynthetic activity and production of more biomass, which ultimately resulted in higher haulm yield. These results are in conformity with the results of Yadav and Malik (2005), Meena et al., (2015), Joshi et al., (2018), Pargi et al., (2018) and Singh et al., (2018).

In the view of the results obtained from the present investigation, it can be concluded that for securing higher seed yield from summer cowpea (Vigna unguiculata L. Walp) raised 
on loamy sand soil, the crop should be fertilized either with recommended dose of fertilizer (20-40-00 kg NPK ha ${ }^{-1}$ ) or apply 4 ton FYM along with seed treatment of $5 \mathrm{~mL}$ PSB $\mathrm{kg}^{-1}$ seed.

\section{References}

Anonymous. 2016. Prospects of Pulses-2016. Publication No.: DPD/Pub, 1(2).

Joshi, J. R., Patel, V. M., Barad, H. L., Macwan, S. M. and Javid, E. 2018. Effect of land configuration and fertilizer management practices on growth, yield and yield attributes and economics of summer cowpea (Vigna unguiculata L.) under south Gujarat condition. International Journal of Current Microbiology and Applied Sciences, 7(1): 1148-1155.

Meena, J. S., Verma, H. P. and Pancholi, P. 2015. Effect of fertility levels and biofertilizers on the growth and yield of cowpea (Vigna unguiculata L. Walp) on sandy loam soil of Rajasthan. An Asian Journal of Soil Science, 10(1): 55-58.

Mohanty, S. and Satyasai, K. J. 2015. Feeling the pulse, Indian pulses sector. NABARD Rural Pulses, Issue X- JulyAugust 2015.

Panse, V. G. and Sukhatme, P. V. 1967. Statistical methods for agricultural workers, ICAR Pub., New Delhi, p, 361.

Pargi, K. L., Leva, R. L., Vaghasiya, H. Y. and Patel, H. A. 2018. Integrated nutrient management in summer cowpea (Vigna unguiculata L.) under south Gujarat conditions, International Journal of Current Microbiology and Applied Sciences, 7(9): 1513-1522.

Singh, R., Singh, V., Singh, P. and Yadav, R. A. 2018. Effect of phosphorus and PSB on yield attributes, economics of summer greengram (Vigna radiata $\mathrm{L}$.). Journalof Pharmacognosy and Phytochemistry, 7(2): 404-408.

Yadav, R. D. and Malik, C. V. S. 2005. Effect of Rhizobium inoculation and various sources of nitrogen on growth and yield of cowpea (Vigna unguiculata L. Walp.). Legume Research, 28(1): 3841.

\section{How to cite this article:}

Dhwani Bartwal and Patel, R. A. 2020. Effect of Chemical Fertilizer, Organic Manure and BioFertilizer on Growth and Yield of Summer Cowpea (Vigna unguiculata L. Walp). Int.J.Curr.Microbiol.App.Sci. 9(11): 599-603. doi: https://doi.org/10.20546/ijcmas.2020.911.073 